\title{
PENGARUH LITERASI EKONOMI DAN KONTROL DIRI TERHADAP PERILAKU PEMBELIAN IMPULSIF UNTUK PRODUK FASHION
}

\author{
Noni Rozaini ${ }^{1 *}$, Bismi Aditya Ginting2) \\ 1) Fakultas Ekonomi Universitas Negeri Medan \\ 2) Alumni Fakultas Ekonomi Universitas Negeri Medan \\ ${ }^{1)}$ E-mail: nonirozaini@gmail.com \\ ${ }^{2)}$ Email: bismi.a.ginting @ gmail.com
}

\begin{abstract}
Permasalahan dalam penelitian ini rendahnya kontrol diri mahasiswa Prodi Pendidikan Bisnis Stambuk 2014 Unimed. Penelitian ini bertujuan untuk mengetahui pengaruh literasi ekonomi dan kontrol diri terhadap perilaku pembelian impulsif mahasiswa Prodi Pendidikan Bisnis Unimed. Populasi dalam penelitian ini adalah seluruh mahasiswa Prodi Pendidikan Bisnis stambuk 2014 Unimed yang berjumlah 76 mahasiswa dan sampel sebanyak 76 mahasiswa dengan teknik total sampling. Teknik pengambilan data menggunakan observasi, dokumentasi, tes dan penyebaran angket. Uji validitas dengan menggunakan teknik analisis product moment dan reliabilitas angket menggunakan rumus Alpha Croanbanch. Persamaan regresi linear berganda menunjukkan $Y=9,270-0,017(X 1)-0,787(X 2)+$ 0,05. Hasil uji t (parsial) menunjukkan literasi ekonomi tidak terdapat pengaruh negatif dan signifikan terhadap perilaku pembelian impulsif. Kontrol diri berpengaruh negatif dan signifikan terhadap perilaku pembelian impulsif. Secara simultan, kategori literasi ekonomi dan kontrol diri berpengaruh negatif dan signifikan terhadap perilaku pembelian impulsif. Hasil uji koefisien determinasi (R2) sebesar 37,1\% dan sisanya dipengaruhi oleh faktor lain di luar penelitian.
\end{abstract}

Kata Kunci : Literasi Ekonomi, Kontrol Diri, Perilaku Pembelian Impulsif. 


\section{PENDAHULUAN}

Globalisasi berasal dari kata globe yang berarti "dunia". Secara harfiah. Globalisasi dapat dikatakan sebagai proses mendunia. Sedangkan secara umum globalisasi diartikan sebagai proses penyebaran unsur-unsur baru khususnya yang menyangkut informasi secara mendunia melalui media cetak dan elektronik. Globalisasi berpengaruh pada segala aspek kehidupan masyarakat baik dari segi politik, ekonomi, sosial budaya maupun keamanan. Globalisasi yang terjadi pada bidang perekonomian disebut dengan globalisasi perekonomian. Globalisasi perekonomian diartikan sebagai suatu proses kegiatan ekonomi dan perdagangan, dimana negara-negara di seluruh dunia menjadi satu kekuatan pasar yang semakin terintegrasi. Globalisasi perekonomian mengharuskan penghapusan seluruh batasan dan hambatan terhadap arus modal, barang, dan jasa. Globalisasi perekonomian di satu pihak akan membuka peluang pasar produk dari dalam negeri ke pasar internasional secara kompetitif, sebaliknya juga membuka peluang masuknya produk-produk global ke dalam pasar domestik.

Pembelian impulsif atau biasa disebut juga unplanned purchase merupakan perilaku seseorang dimana orang tersebut tidak merencanakan sesuatu dalam berbelanja. Konsumen yang melakukan pembelian impulsif tidak berpikir untuk membeli suatu produk atau merek tertentu. Mereka langsung melakukan pembelian karena ketertarikan pada merek atau produk saat itu juga. Menurut Rook dan Fisher (1995: 306) pembelian impulsif diartikan sebagai kecenderungan konsumen untuk membeli secara spontan, reflek, tiba-tiba, dan otomatis. Dari definisi tersebut terlihat bahwa pembelian impulsif merupakan sesuatu yang alamiah dan merupakan reaksi yang cepat.

Pada umumnya mahasiswa telah diberi kepercayaan dan tanggung jawab dalam mengelola keuangannya sendiri. Dengan demikian mereka merasa bebas menggunakan uang yang dimiliki tanpa pengawasan langsung dari orang tua, hal tersebut menyebabkan mahasiswa seringkali kurang rasional dalam membelanjakan uangnya. Para remaja atau mahasiswa lebih sering menggunakan emosi sehingga mengarah pada pembelian secara spontanitas. Pembelian impulsif seringkali terjadi pada produk-produk yang dirasa cukup menarik bagi kelompok konsumen ini, salah satunya adalah produk fashion yang terdiri dari pakaian, celana, sepatu, sandal, jam tangan, kerudung, topi dan tas yang berfungsi sebagai sarana meningkatkan self image dan mood. Melalui produk fashion tersebut dapat terlihat lebih modis dan menawan.

Fenomena tersebut terjadi karena remaja saat ini cenderung memiliki kontrol diri yang rendah, termasuk dalam perilaku pembelian sehingga mereka berperilaku impulsif. Pada dasarnya, pembelian impulsif dapat ditekan dan bahkan dihindari apabila mahasiswa memiliki sistem pengendalian internal pada dirinya yang disebut dengan kontrol diri. Kontrol diri adalah perasaan bahwa seseorang dapat membuat keputusan dan mengambil tindakan yang efektif untuk menghasilkan suatu hal yang diinginkan dan menghindari suatu hal yang tidak diinginkan. Sesuai dengan yang diungkapkan Hoyri (2014: 52) bahwa kontrol diri merupakan kemampuan individu untuk menentukan perilakunya berdasarkan standar tertentu seperti moral, nilai, dan aturan di masyarakat agar mengarah pada perilaku positif.

Terkait dengan perilaku konsumsi remaja atau mahasiswa, pendidikan memegang peranan penting dalam meningkatkan sumber daya manusia berkualitas. Dengan kata lain, orang dianggap belajar jika menunjukkan perubahan-perubahan tingkah laku dalam hidupnya, sehingga literasi ekonomi menjadi hal penting. Sina (2012: 135) berpendapat bahwa literasi ekonomi merupakan alat yang berguna untuk mengubah perilaku dari tidak cerdas menjadi cerdas. Seperti bagaimana memanfaatkan pendapatan untuk menabung, berinvestasi, proteksi dan memenuhi kebutuhan hidup.

Literasi ekonomi juga berguna untuk membuka persepsi yang terbelenggu akibat kurangnya pengetahuan tentang biaya/manfaat. Oleh sebab itu mahasiswa dituntut untuk bisa meminimalisir perilaku konsumtif dalam berkonsumsi. Adapun indikator dalam uji literasi ekonomi yang dikembangkan oleh NCEE dalam penelitian ini ialah ekonomi mikro dan makro.

Hasil pengamatan yang dilakukan oleh peneliti dapat dinyatakan bahwa Mahasiswa Program Studi Pendidikan Bisnis Stambuk 2014 Fakultas ekonomi Universitas Negeri Medan memiliki tingkat literasi ekonomi yang berbeda. Hal ini dibuktikan dengan perbedaan kategori nilai yang diambil dari 59 mahasiswa dari mata 
kuliah Teori ekonomi sebagai tolak ukur literasi ekonomi yang dapat dipaparkan sebagai berikut:

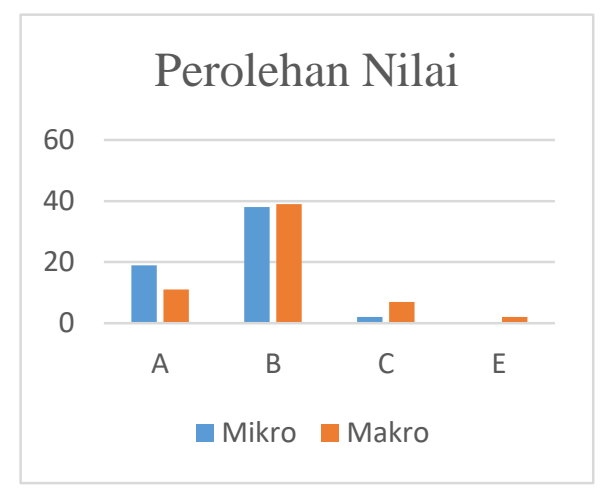

\section{Gambar 1 \\ Nilai Teori Ekonomi Mahasiswa Program Studi Pendidikan Bisnis Stambuk 2014}

Kategori diatas menunjukkan mayoritas mahasiswa cenderung mendominasi nilai B yang berarti tingkat literasi ekonomi dikategorikan kompeten dengan rentang nilai 80-89. Ditinjau dari fenomena tersebut, seharusnya seseorang yang memiliki tingkat literasi ekonomi yang baik akan mampu memanfaatkan uang yang dimilikinya dengan baik. Namun faktanya masih banyak mahasiswa Pendidikan Bisnis Stambuk 2014 yang tidak mampu memanfaatkan uang yang dimilikinya dengan baik dan lebih mengikuti kengininan dibandingkan kebutuhannya dalam membeli suatu produk.

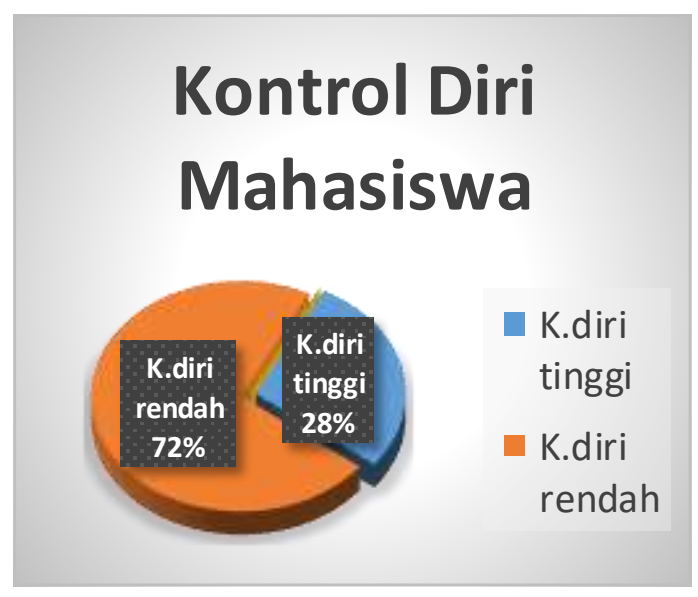

Gambar 2

Kontrol Diri Mahasiswa Prodi Pendidikan Bisnis Stambuk 2014

Dari hasil observasi yang peneliti lakukan, bahwa mahasiswa fakultas ekonomi khususnya mahasiswa Pendidikan Bisnis Stambuk 2014 memiliki tingkat kontrol diri yang rendah. Dari 25 mahasiswa Pendidikan Bisnis yang diteliti, diperoleh data mahasiswa yang memiliki kontrol diri rendah $72 \%$ dan mahasiswa yang memiliki kontrol diri tinggi
NIAGAWAN Vol 8 No 1 Maret 2019

$28 \%$, Dimana dari $72 \%$ mahasiswa yang memiliki kontrol diri rendah, selalu tergesa-gesa dalam memilih sesuatu dan mudah terpengaruh oleh bujukan penjual. Dan 28\% Mahasiswa Pendidikan Bisnis Stambuk 2014 tidak pernah melakukan kedua hal tersebut.

\section{TINJAUAN PUSTAKA \\ Perilaku Pembelian Impulsif}

Menurut Lisda (2010: 56) pembelian impulsif (impulsive buying) adalah proses pembelian suatu barang, dimana pembeli tidak mempunyai niat untuk membeli sebelumnya, dapat dikatakan pembelian tanpa rencana atau pembelian seketika. Sedangkan menurut Mowen dan Minor (2002: 10) pembelian impulsif (impulse purchase) adalah tindakan membeli yang sebelumnya tidak diakui secara sadar sebagai hasil dari suatu pertimbangan, atau niat membeli yang terbentuk sebelum memasuki toko. Dapat dikatakan bahwa impulse buying merupakan sesuatu yang alamiah dan merupakan reaksi yang cepat.

Sutisna (2002: 17) menjelaskan bahwa pembelian impulsif terjadi ketika konsumen mengambil keputusan pembelian yang mendadak. Dorongan untuk melakukan pembelian begitu kuat, sehingga konsumen tidak lagi berpikir rasional dalam pembeliannya. Sedangkan menurut Schiffman dan Kanuk (2007: 511) bahwa pembelian impulsif merupakan keputusan yang emosional atau menurut desakan hati. Emosi dapat menjadi sangat kuat dan berlaku sebagai dasar dari motif pembelian yang domain.

Dari beberapa pengertian di atas, maka dapat disimpulkan bahwa pembelian impulsif adalah perilaku membeli konsumen dimana konsumen tersebut melakukan pembelian tanpa adanya perencanaan, terjadi dengan tiba-tiba, dan keinginan yang kuat untuk membeli sesuatu dengan segera tanpa adanya suatu pertimbangan untuk akibat yang akan dihadapi. Sehingga konsumen tidak lagi berpikir rasional dalam perilaku pembelian.

\section{Produk Fashion}

Produk (product) didefinisikan sebagai segala sesuatu yang dapat ditawarkan atau diperjualbelikan kepada pasar agar menarik perhatian, akuisisi, penggunaan, atau konsumsi yang dapat memuaskan suatu keinginan atau kebutuhan (Kotler \& Armstrong, 2008: 266). Kata produk berasal dari bahasa inggris product yang berarti "sesuatu yang diproduksi oleh 
tenaga kerja atau sejenisnya". Dalam arti luas, produk meliputi objek-objek fisik, jasa, acara, orang, tempat, organisasi, ide, atau bauran entitas-entitas ini.

Bagi seorang remaja atau mahasiswa, penampilan dianggap penting untuk menunjang keberhasilan di semua bidang kehidupan sehingga orang sering menghabiskan banyak waktu dan uang untuk membeli produk fashion. Fashion itu sendiri memiliki banyak arti, seperti yang dikemukakan Solomon dalam bukunya 'Consumer Behaviour: European Perspective' fashion adalah proses penyebaran sosial dimana sebuah gaya mengacu pada kombinasi beberapa atribut. Agar dapat dikatakan 'in fashion', kombinasi tersebut haruslah dievaluasi secara positif oleh sebuah reference group (Dian Savitrie, 2008: 13-14). Sehingga, dapat dikatakan bahwa fashion merupakan tanda dari suatu periode waktu, seringkali fashion menggambarkan kebudayaan, perasaan, pemikiran dan gaya hidup orang-orang dalam satu kurun waktu.

Berdasarkan definisi di atas, dapat disimpulkan bahwa produk fashion merupakan sebuah produk yang mempunyai ciri-ciri khusus yang tepat dan mewakili style yang sedang trend dalam kurun waktu tertentu. Selain itu, produk fashion merupakan elemen penting dalam mendukung penampilan dan presentasi diri remaja dengan harapan akan diterima, dalam kelompok yang dikehendakinya.

\section{Literasi Ekonomi}

Literasi dalam bahasa Inggris yaitu Literacy berasal dari bahasa Latin littera atau huruf yang artinya melibatkan penguasaan sistem-sistem tulisan dan konvensi-konvensi yang menyertainya. Cope dan Kalantzis dalam (Abidin,Yunus, dkk: 2017), literasi merupakan elemen terpenting dalam proyek pendidikan modern.

Abidin (2017), menyatakan bahwa Secara tradisional, literasi dipandang sebagai kemampuan membaca dan menulis. Orang yang dapat dikatakan literat dalam pandangan ini adalah orang yang mampu membaca dan menulis atau bebas buta huruf. Pengertian literasi selanjutnya berkembang menjadi kemampuan membaca, menulis, berbicara dan menyimak. Sejalan dengan perjalanan waktu, definisi literasi telah bergeser dari pengertian yang sempit menuju pengertian yang lebih luas mencakup berbagai bidang penting lainnya.
Eisner (Kist,2017: 4) yang menyatakan bahwa multiliterasi merupakan kemampuan membaca, menulis puisi, membagi, melukis, menari, menulis novel ataupun kemampuan berkontak dengan berbagai media yang memerlukan literasi. Dengan demikian, Eisner berpendapat bahwa literasi dapat dipandang sebagai cara untuk menemukan dan membuat makna dari berbagai bentuk representasi yang ada di sekitar kita.

Dari beberapa pendapat ahli diatas dapat didefenisikan bahwa literasi merupakan kemampuan seseorang dalam membaca, menulis, menyimak sesuatu hal yang terjadi di kehidupan yang kemudian dapat memberi pendapat atau saran terhadap sesuatu hal yang didapat dari membaca dan juga didapat dari beberapa media teknologi.

\section{Kontrol Diri}

Menurut Ghufron (2010: 11) kontrol diri merupakan suatu kecakapan individu dalam kepekaan membaca situasi diri dan lingkungannya. Selain itu, juga kemampuan untuk mengontrol dan mengelola faktor-faktor perilaku sesuai dengan situasi dan kondisi untuk menampilkan diri dalam melakukan sosialisasi kemampuan untuk mengendalikan perilaku, kecenderungan menarik perhatian, keinginan mengubah perilaku agar sesuai untuk orang lain, menyenangkan orang lain, selalu konform dengan orang lain, dan menutupi perasaannya. Sedangkan menurut Syamsul (2010: 107) kontrol diri merupakan individu untuk mengendalikan dorongan-dorongan, baik dari dalam maupun dari luar diri individu. Individu yang memiliki kemampuan kontrol diri akan membuat keputusan dan mengambil langkah tindakan yang efektif sehingga menghasilkan sesuatu yang diinginkan dan menghindari akibat yang tidak diinginkan.

Menurut Goldfried dan Merbaum (dalam Ghufron, 2010: 12) mendefinisikan kontrol diri sebagai suatu kemampuan untuk menyusun, membimbing, mengatur dan mengarahkan bentuk perilaku yang dapat membawa individu ke arah konsekuensi positif. Sejalan dengan pendapat Tangney yang dikutip dalam Hoyri (2014: 52) bahwa kontrol diri merupakan "kemampuan individu untuk menentukan perilakunya berdasarkan standar tertentu seperti moral, nilai dan aturan di masyarakat agar mengarah pada perilaku positif'. 


\section{METODE PENELITIAN}

Penelitian ini dilaksanakan di Fakultas Ekonomi Universitas Negeri Medan yang berlokasi di Jalan Willem Iskandar Pasar V Medan Estate. Populasi dalam penelitian ini adalah seluruh mahasiswa pendidikan bisnis stambuk 2014 Unimed yang berjumlah 76 mahasiswa. Berdasarkan ketentuan tersebut, maka sampel dalam penelitian ini ditetapkan sebanyak 76 orang. Uji instrument menggunakan uji validitas dan reliabilitas angket. Teknik analisa data dalam penelitian ini menggunakan analisis regresi berganda, uji hipotesis parsial (uji t), uji hipotesis simultan (uji f) dan koefisien determinasi (R2).

\section{HASIL DAN PEMBAHASAN}

Berdasarkan hasil perhitungan hipotesis secara parsial menunjukkan bahwa untuk variabel literasi ekonomi diperoleh $\mathrm{t}_{\text {hitung }}=$ 0,275 dengan taraf signifikan $-0,784$, karena $\mathrm{t}_{\text {hitung }}<\mathrm{t}_{\text {tabel }}(-0,275<1,725)$ dan taraf signifikan yang diperoleh $-0,784>0,05$. Hal ini membuktikan bahwa tidak ada pengaruh negatif dan signifikan antara Literasi Ekonomi (X1) terhadap Perilaku Pembelian Impulsif (Y) Mahasiswa Program Studi Pendidikan Bisnis Stambuk 2014 UNIMED. Maka hipotesis ditolak.

Sementara dari variabel Kontrol Diri $\mathrm{t}_{\text {hitung }}=-6,549$ dengan taraf signifikan 0,000 karena $t_{\text {hitung }}>\mathrm{t}_{\text {tabel }}(-6,549>1,725)$ dan taraf signifikan yang diperoleh $0,000<0,05$, hal ini berarti ada pengaruh negatif dan signifikan antara Kontrol Diri $\left(\mathrm{X}_{2}\right)$ terhadap Perilaku Pembelian Impulsif (Y) Mahasiswa Program Studi Pendidikan Bisnis Stambuk 2014 UNIMED. Maka hipotesis diterima. bawah ini

Dapat dilihat dalam bentuk tabel di

\begin{tabular}{|c|c|c|c|c|c|}
\hline \multirow{3}{*}{ Model } & eff & $\mathrm{tts}^{\mathrm{a}}$ & & & \\
\hline & \multicolumn{2}{|c|}{$\begin{array}{l}\text { Unstandardi } \\
\text { zed } \\
\text { Coefficients }\end{array}$} & $\begin{array}{c}\text { Standar } \\
\text { dized } \\
\text { Coeffici } \\
\text { ents }\end{array}$ & \multirow[t]{2}{*}{$\mathrm{t}$} & \multirow[t]{2}{*}{ Sig. } \\
\hline & B & $\begin{array}{c}\text { Std. } \\
\text { Error }\end{array}$ & Beta & & \\
\hline $\begin{array}{l}\text { (Const } \\
\text { ant) }\end{array}$ & $\begin{array}{r}9,27 \\
0\end{array}$ & $\begin{array}{r}7,36 \\
5\end{array}$ & & $\begin{array}{r}1,25 \\
9\end{array}$ & ,212 \\
\hline $\begin{array}{cc}1 & \text { Literas } \\
& \text { Ekkon } \\
& \text { omi }\end{array}$ &,- 017 & ,063 &,- 026 & 275 & ,784 \\
\hline
\end{tabular}

NIAGAWAN Vol 8 No 1 Maret 2019

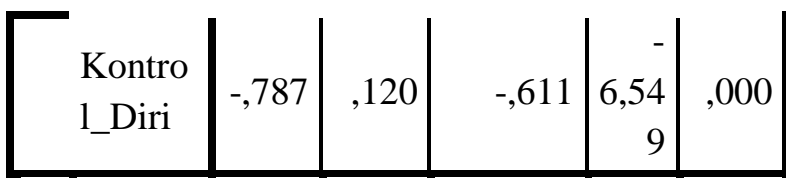

a. Dependent Variable: Perilaku_Pembelian_Impulsif

Dari pengujian hipotesis secara simultan antara literasi ekonomi dan kontrol diri terhadap perilaku pembelian impulsif diketahui bahwa nilai $F_{\text {hitung }}=21,522$ sedangkan nilai $F_{\text {tabel }} 3,12$ dengan taraf signifikan $0,000<0,05$ maka dapat disimpulkan bahwa nilai $F_{\text {hitung }}>F_{\text {tabel }}(30,375>$ 3,12 ), yang berarti hipotesis diterima bahwa variabel independen berpengaruh simultan dan signifikan terhadap variabel dependen.

\section{ANOVA $^{\mathrm{a}}$}

\begin{tabular}{|c|c|c|c|c|}
\hline \multicolumn{2}{|c|}{ Model } & $\begin{array}{c}\text { Sum of } \\
\text { Squares }\end{array}$ & $\bar{F}$ & Sig. \\
\hline \multirow{3}{*}{1} & Regression & 3151,113 & $\begin{array}{r}21.5 \\
20\end{array}$ & $.000^{\mathrm{b}}$ \\
\hline & Residual & 5344,084 & & \\
\hline & Total & 8495,197 & & \\
\hline
\end{tabular}

a. Dependent Variable: Perilaku_Pembelian_Impulsif

b. Predictors: (Constant), Kontrol_Diri, Literasi_Ekonomi

Masing-masing variabel bebas juga memberikan pengaruh/ sumbangan terhadap variabel terikat dengan uji $\mathrm{R}^{2}$ (Uji Determinasi) sebesar 0,371 atau dengan kata lain nilai koefisien determinasinya adalah sebesar $0,371 \times 100 \%=$ $37,1 \%$. Dari data tersebut maka dapat kita tarik kesimpulan bahwa dalam penelitian ini variabel Literasi Ekonomi (X1) dan Kontrol Diri (X2) memberikan sumbangan pengaruh sebesar $37,1 \%$ terhadap Perilaku Pembelian Impulsif (Y) dan sisanya $62,9 \%$ disumbangkan oleh faktor lain diluar dari penelitian ini.

\section{Literasi Ekonomi terhadap Perilaku Pembelian Impulsif}

Pada masyarakat modern abad ke-20, konsumerisme menjadi bagian utama dalam hidup secara terus-menerus, masyarakat tersebut merupakan orang yang tidak mengkonsumsi barang bukan karena membutuhkan secara fungsional, melainkan karena tuntutan prestise (gengsi), status atau sekedar gaya hidup (life style), hal ini sering dilakukan masyarakat pada umur remaja. Fakta tersebut menunjukkan bahwa mahasiswa yang termasuk remaja tersebut masih mementingkan hal-hal yang berkaitan dengan eksistensi diri dan belum menjadikan pengelolaan keuangan yang baik 
dan pengetahuan ekonomi (literasi ekonomi) sebagai bekal masa depan.

Dari hasil penelitian diperoleh nilai thitung sebesar $-0,275<1,725$ dengan nilai signifikansi t sebesar 0,784 >0,05. Maka dapat disimpulkan bahwa tidak terdapat pengaruh literasi ekonomi terhadap perilaku pembelian impulsif untuk produk fashion pada mahasiswa prodi pendidikan tata niaga stambuk 2014.

Berdasarkan hasil deskripsi data penelitian dapat diketahui bahwa tingkat literasi ekonomi mahasiswa Prodi Pendidikan Bisnis Universitas Negeri Medan Stambuk 2014 termasuk dalam kategori sedang. Meskipun kecenderungan literasi ekonomi menunjukkan kecenderungan sedang, namun hasil penelitian menunjukkan bahwa literasi ekonomi tidak berpengaruh terhadap perilaku pembelian impulsif. Dapat disimpulkan bahwa baik mahasiswa yang memiliki tingkat literasi ekonomi tinggi maupun rendah tidak memiliki perbedaan dalam perilaku pembelian impulsif.

Pendidikan memiliki peranan penting dalam meningkatkan sumber daya manusia berkualitas. Dengan kata lain, orang dianggap belajar jika menunjukkan perubahan-perubahan tingkah laku dalam hidupnya, sehingga literasi ekonomi menjadi hal penting. Sina (2012: 135) berpendapat bahwa literasi ekonomi merupakan alat yang berguna untuk mengubah perilaku dari tidak cerdas menjadi cerdas. Seperti bagaimana memanfaatkan pendapatan untuk menabung, berinvestasi, proteksi dan memenuhi kebutuhan hidup. Dengan memiliki literasi ekonomi yang baik, mahasiswa mampu memikirkan hal yang lebih dibutuhkan sebelum membeli suatu produk ketika berbelanja.

Menurut penelitian Rook (1987: 193195) pembelian impulsif memiliki beberapa karakteristik yaitu: terjadi secara spontan (tibatiba), tidak terencana, cepat, tidak terkendali dan tidak mempertimbangkan akibat yang akan timbul selanjutnya. Oleh karena itu, ketika dalam situasi pembelian terutama pembelian impulsif, mahasiswa tidak sempat atau tidak ada waktu untuk mengingat dan memperhitungkan bagian-bagian dari konsep ekonomi yang telah dipelajarinya. Sehingga tingkat literasi ekonomi yang dimiliki tidak berpengaruh terhadap perilaku impulsif.

\section{Kontrol Diri terhadap Perilaku Pembelian Impulsif}

Pada umumnya mahasiswa telah diberi

kepercayaan dan tanggung jawab dalam

\section{NIAGAWAN Vol 8 No 1 Maret 2019}

mengelola keuangannya sendiri. Dengan demikian mereka merasa bebas menggunakan uang yang dimiliki tanpa pengawasan langsung dari orang tua, hal tersebut menyebabkan mahasiswa seringkali kurang rasional dalam membelanjakan uangnya. Para remaja atau mahasiswa lebih sering menggunakan emosi sehingga mengarah pada pembelian impulsif. Pembelian impulsif seringkali terjadi pada produk-produk yang dirasa cukup menarik bagi kelompok konsumen ini, salah satunya adalah produk fashion yang terdiri dari pakaian, celana, sepatu, sandal, jam tangan, kerudung, topi, dan tas yang berfungsi sebagai sarana meningkatkan self image dan mood. Melalui produk fashion tersebut dapat terlihat lebih modis dan menawan.

Fenomena tersebut terjadi karena remaja saat ini cenderung memiliki kontrol diri yang rendah, termasuk dalam perilaku pembelian sehingga mereka berperilaku impulsif. Pada dasarnya, pembelian impulsif dapat ditekan dan bahkan dihindari apabila mahasiswa memiliki sistem pengendalian internal pada dirinya yang disebut dengan kontrol diri. Hoyri (2014: 52) berpendapat bahwa Kontrol diri adalah perasaan bahwa seseorang dapat membuat keputusan dan mengambil tindakan yang efektif untuk menghasilkan suatu halyang diinginkan dan menghinari suatu hal yang tidak diinginkan. Dengan memiliki kontrol diri yang baik, mahasiswa mampu menghindari perilaku pembelian impulsif ketika melakukan pembelian suatu produk.

Dari hasil penelitian diperoleh nilai thitung sebesar $-6,549>1,725$ dengan nilai signifikan 0,000>0,05. Maka dapat disimpulkan bahwa terdapat pengaruh kontrol diri terhadap perilaku pembelian impulsif untuk produk fashion pada mahasiswa prodi pendidikan tata niaga stambuk 2014.

Berdasarkan deskripsi variabel kontrol diri, dapat diketahui bahwa kontrol diri mahasiswa Pendidikan Bisnis stambuk 2014 termasuk dalam kategori kurang baik. Semakin tinggi kontrol diri seseorang, maka semakin rendah perilaku pembelian impulsif. Sebaliknya semakin rendah kontrol diri, maka semakin tinggi perilaku pembelian impulsif untuk produk fashion pada mahasiswa Pendidikan Bisnis 2014

Hal ini sesuai dengan pendapat yang dikemukakan oleh Chaplin (dalam Dira Sarah, 2014: 316) bahwa kontrol diri pada dasarnya adalah kemampuan untuk membimbing tingkah laku sendiri, kemampuan untuk menekan atau 
merintangi dorongan atau tingkah laku impulsif. Sehingga perilaku pembelian impulsif dapat dihindari ketika remaja atau mahasiswa memiliki kontrol diri yang baik.

\section{Literasi Ekonomi dan Kontrol Diri terhadap Perilaku Pembelian Impulsif}

Literasi ekonomi dan kontrol diri secara bersama-sama mempunyai pengaruh yang signifikan terhadap perilaku pembelian impulsif pada mahasiswa Prodi Pendidikan Bisnis Universitas Negeri Medan stambuk 2014. Literasi ekonomi berguna untuk membuka persepsi yang terbelenggu akibat kurangnya pengetahuan tentang biaya/manfaat. Oleh karena itu dengan memiliki literasi ekonomi yang baik akan membantu mahasiswa dalam memikirkan manfaat suatu produk sebelum membelinya.

Hasil penelitian dan pengolahan data bahwa persentase sumbangan variabel independen, yaitu literasi ekonomi dan kontrol diri terhadap variabel dependen pengelolaan keuangan pribadi sebesar 37,1\%. Dengan demikian perubahan perilaku pembelian impulsif dipengaruhi oleh literasi ekonomi dan kontrol diri sebesar $37,1 \%$ dan sisanya sebesar $62,9 \%$ dipengaruhi oleh faktor-faktor di luar penelitian. maka dapat disimpulkan bahwa literasi ekonomi dan kontrol diri memiliki pengaruh yang negatif dan signifikan terhadap pengelolaan keuangan pribadi mahasiswa Pendidikan Bisnis Stambuk 2014 UNIMED.

Hal tersebut sesuai dengan yang diungkapkan Hoyri (2014: 52) bahwa kontrol diri merupakan kemampuan individu untuk menentukan perilakunya berdasarkan standar tertentu seperti moral, nilai, dan aturan di masyarakat agar mengarah pada perilaku positif. Sehingga mahasiswa dapat menghindari perilaku pembelian impulsif jika memiliki kontrol diri yang baik. Pendidikan juga memegang peranan penting dalam meningkatkan sumber daya manusia berkualitas. Dengan kata lain, orang dianggap belajar jika menunjukkan perubahanperubahan tingkah laku dalam hidupnya, sehingga literasi ekonomi menjadi hal penting. Sina (2012: 135) berpendapat bahwa literasi ekonomi merupakan alat yang berguna untuk mengubah perilaku dari tidak cerdas menjadi cerdas. Seperti bagaimana memanfaatkan pendapatan untuk menabung, berinvestasi, dan memenuhi kebutuhan hidup.

Implikasi dari hasil penelitian ini ditunjukkan kepada Mahasiswa Pendidikan Bisnis stambuk 2014 UNIMED agar lebih memahami pengetahuan tentang literasi ekonomi dan kontrol diri yang baik agar menjadi mahasiswa cerdas dan bisa lebih mengutamakan kebutuhan dibandingkan keinginan ketika membeli suatu produk fashion.

\section{KESIMPULAN DAN SARAN}

Kesimpulan

Hasil analisis regresi linear berganda diperoleh persamaan garis linear $\mathrm{Y}=9,270$ $0,017(\mathrm{X} 1)-0,787(\mathrm{X} 2)$. Dari hasil analisis regresi linear berganda diperoleh hasil bahwa variabel literasi ekonomi (X1) dan kontrol diri (X2) berpengaruh terhadap perilaku pembelian impulsif (Y) secara linear.

Tidak terdapat pengaruh literasi ekonomi terhadap perilaku pembelian impulsif untuk produk fashion pada mahasiswa Pendidikan Bisnis Angkatan 2014 UNIMED.

Terdapat pengaruh negatif dan signifikan kontrol diri terhadap perilaku pembelian impulsif untuk produk fhasion pada mahasiswa Pendidikan Bisnis Angkatan 2014 UNIMED.

Terdapat pengaruh signifikan literasi ekonomi dan kontrol diri terhadap perilaku pembelian impulsif untuk produk fashion pada mahasiswa Pendidikan Bisnis Angkatan 2014 UNIMED. Hal ini ditunjukkan dengan nilai Fhitung sebesar 21,522 dengan nilai signifikansi F sebesar 0,000. Karena nilai sig $\mathrm{F}<0,05$, maka dapat disimpulkan bahwa terdapat pengaruh signifikan literasi ekonomi dan kontrol diri terhadap perilaku pembelian impulsif. Koefisien determinasi (R2) sebesar 0,371, berarti bahwa $37,1 \%$ perilaku pembelian impulsif mahasiswa dapat dijelaskan oleh variabel literasi ekonomi dan kontrol diri. Sedangkan sisanya 62,9\% dijelaskan oleh variabel lain yang tidak diteliti dalam penelitian ini.

Saran

Meskipun dalam penelitian ini literasi ekonomi tidak berpengaruh, mahasiswa diharapkan lebih mendalami literasi ekonomi atau pemahaman konsep-konsep dasar ekonomi, sehingga tidak hanya menguasai secara materi yang nantinya akan cepat lupa, namun dapat menerapkannya dalam kehidupan sehari-hari.

Mempertahankan dan meningkatkan aspek psikologi yaitu kemampuan mengontrol perilaku agar tidak mudah terpengaruh oleh dampak negatif dari lingkungan sekitar termasuk dalam perilaku konsumsi. 
Bagi peneliti selanjutnya yang hendak meneliti maupun mengembangkan penelitian serupa, peneliti menyarankan agar mempertimbangkan variasi dari sampel yang akan diteliti dan tentunya dengan variabel lain yang tidak diteliti dalam penelitian ini.

\section{REFERENSI}

Albritton, Frank P. 2006 Performance on Tests of Economic Literacy: A Comparison of Face-to-Face with Online Instruction. First Monday (peerreviewed journal on the internet). Vol.11 No.10

Budiwati, Neti. 2014. Analisis Literasi Ekonomi dan Perilaku Konsumen. Disertasi. Bandung: Universitas Pendidikan Indonesia.

Divianto. 2013. Pengaruh Faktor-Faktor In-Store Promotion terhadap Impulse Buying Decision pada Konsumen Hypermart PIM. Jurnal Ekonomi dan Informasi Akuntansi. Vol.3 No.1.hlm. 94-104.

Ghufron, M. N. \& Rini R. S. (2010). Teori-Teori

Psikologi. Yogyakarta: Ar-Ruzz Media.

Gozhali, Imam. 2011. Aplikasi Analisis Multivariate dengan Program IBM SPSS 19. Semarang: Undip.

Hoyri S, Imam. 2014. Kontrol Diri dan Perilaku

Konsumtif pada Siswa SMA (Ditinjau dari Lokasi Sekolah). Jurnal Online Psikologi. Vol. 2 No.1.hlm. 46-61.

Jappelli, T. 2009. Economic Literacy: An Internasional Comparison. CFS Working Paper. No. 238.

Kotler, Philip \& Armstong, Gary. 2008. PrinsipPrinsip Pemasaran Edisi Keduabelas Jilid I. Alih bahasa: Bob Sabran. Jakarta: Erlangga.
NIAGAWAN Vol 8 No 1 Maret 2019

Mankiw, N. Gregory. 2006. Pengantar Ekonomi Mikro Edisi Ketiga. Jakarta: Salemba.

Mayasari, Mila. 2012. Pengaruh Penguasaan Konsep Ekonomi, Konformitas Teman Sebaya dan Emosi terhadap Perilaku Pembelian Impulsif untuk Produk Aksesoris Remaja pada Siswa Kelas XI Jurusan IPS SMA N 10 Yogyakarta. Skripsi. Yogyakarta: Universitas Negeri Yogyakarta.

Mowen, John C \& Minor, Michael. 2002. Perilaku Konsumen Jilid 1. Alih Bahasa: Lina Salim. Jakarta: Erlangga.

Nopirin. 2008. Pengantar Ilmu Ekonomi Makro \& Mikro. Yogyakarta: BPFE

Peter G Sina. 2012. Literasi Ekonomi. Diakses dari http://ekonomi.kompasiana.com/mon eter/2012/05/01/literasi-ekonomi459579.html. Pada 19 Maret 2018.

Peter G Sina. 2012. Analisis Literasi Ekonomi. Jurnal Economia. Vol.8 No.2.hlm. 135-143.

Purnomo, Herdadu. 2013. Seperempat Masyarakat RI Pengeluarannya Lebih Besar dari Pendapatan. Diakses dari http://news.detik.com/transisipreside n/read/2013/12/08/. Pada 18 Maret 2018.

Putong, Iskandar. 2002. Pengantar Ekonomi Mikro dan Makro. Jakarta: Ghalia Indonesia.

Rahmasari, Lisda. 2010. Menciptakan Impulse Buying. Majalah Ilmiah Informatika. Vol.1 No.3.hlm. 56-68.

Rook, D.W. \& Fisher, R.J. 1995. Normative Influences on Impulsive Buying. Journal of Consumer Research. Vol.22. hlm. 305-313. 
Rook, D.W. 1987. The Buying Impulse. Journal of Consumer Research. Vol.14 No.2.hlm 189-199.

Sarah, Dira. 2014. Peran Kontrol Diri Terhadap Pembelian Impulsif pada Remaja Berdasarkan Perbedaan Jenis Kelamin di Samarinda. eJournal Psikologi. Vol. 1 No.3.hlm.313-323.

Savitri, Dian. 2008. Pola Perilaku Pembelian Produk Fashion pada Konsumen Wanita (Sebuah Studi Kualitatif pada Mahasiswa FE UI dan Pengunjung Butik N.y.l.a). Skripsi. Jakarta: Universitas Indonesia.

Schiffman, L.G. \& Kanuk, Leslie. L. 2007. Consumer Behavior. America: Pearson Prentice Hall.

Sugiyono. 2010. Metode Penelitian Administrasi Dilengkapi dengan Metode R\&D. Bandung: Alfabeta.

Suharsimi Arikunto. 2013. Dasar-Dasar Evaluasi Pendidikan. Jakarta: Bumi Aksara.

Sumartono. 2002. Terperangkap dalam Iklan: Menerobos Imbas Pesan Iklan Televisi. Bandung: Alfabeta.

Sutisna. 2002. Perilaku Konsumen dan Komunikasi Pemasaran. Bandung: PT Remaja Rosdakarya.

Sutrisno Hadi. 2004. Analisis Regresi. Yogyakarta: Penerbit ANDI

Syamsul, B.T. 2010. Psikologi Pendidikan Berbasis Analisis Empiris Aplikatif. Jakarta: Kencana.

Tania Varerina. 2010. Perilaku Pembelian Impulsif Produk Pakaian Masyarakat Urban di Kota Jakarta dan Bandung. Tesis. Jakarta: Universitas Indonesia.

Wathani, Fikrah. 2009. Perbedaan Kecenderungan Pembelian Impulsif Produk Pakaian Ditinjau dari Peran
NIAGAWAN Vol 8 No 1 Maret 2019 Gender. Skripsi. Sumatera Utara: Universitas Sumatera Utara.

Wibowo, Lili Adi. 2008. Menata Produk. Makalah, Pendidikan dan Latihan Profesi Guru (PLPG) Bidang Keahlian Manajemen Bisnis. Bandung: Universitas Pendidikan Indonesia.

Wijaya, Rezky Ananda. 2017. Analisis Pengaruh Literasi Ekonomi dan Gaya Hidup Terhadap Minat Menulis Karya Mahasiswa Pendidikan Ekonomi Unimed. Medan: Unimed. Skripsi 